\title{
KORELASI ANTARA METODE BERMAIN PERAN DENGAN KETERAMPILAN BERBICARA SISWA SEKOLAH DASAR
}

\author{
Itsna Oktaviyanti ${ }^{1}$, Nabilah Khairuddin ${ }^{2}$ \\ ${ }^{1}$ PGSD FKIP Universitas Mataram: itsna@unram.ac.id \\ ${ }^{2}$ PGSD FKIP Universitas Mataram: nabilakh3876@gmail.com
}

Artikel Info

$\begin{array}{lr}\text { Kata } & \text { Kunci: } \\ \text { peran, } & \text { bermain } \\ \text { berbicara } & \text { keterampilan }\end{array}$

\begin{abstract}
Abstrak
Masalah dalam penelitian ini adalah kurangnya keterampilan berbicara siswa kelas III di SDN 46 Mataram yang mengakibatkan kurangnya interaksi antara guru dan siswa didalam kelas. Hal tersebut dikarenakan sikap siswa yang masih pasif dan memiliki keterampilan berbicara yang kurang baik. Penelitian ini bertujuan untuk mengetahui korelasi antara penerapan metode bermain peran terhadap keterampilan berbicara siswa. Jenis penelitian yang digunakan dalam penelitian ini adalah penelitian korelasi deskriptif, adapun populasi dalam penelitian ini adalah siswa kelas III SDN 46 Mataram dan sampel yaitu siswa kelas III SDN 46 Mataram yang berjumlah 30 orang. Untuk penentuan sampel digunakan Teknik nonprobablity sampling yaitu sampel jenuh. Pengumpulan data dalam penelitian ini dengan metode observasi, angket, wawancara dan dokumentasi. Hasil penelitian menunjukkan bahwa siswa melaksanakan pembelajaran dengan baik menggunakan metode bermain peran, selain itu siswa lebih antusias dengan menunjukkan keaktifan dalam berbicara, percaya diri untuk maju ke depan dan tidak malu untuk bertanya kepada guru. Analisis data yang digunakan yaitu rumus product moment korelasi. Berdasarkan hasil perhitungan menggunakan SPSS 16.0, didapatkan hasil penelitian bahwa terdapat korelasi yang signifikan antara penerapan metode bermain peran dengan keterampilan berbicara siswa kelas III SDN 46 Mataram tahun pelajaran 2019/2020, yakni nilai signifikansi sebesar 0,002 yang berarti $<0,05$ dan juga memiliki tingkat korelasi 0,613 berada pada kategori kuat.
\end{abstract}

\section{A. PENDAHULUAN}

Bahasa merupakan media yang dipakai manusia untuk menyampaikan pemikiran atau penalaran, sikap dan perasaannya. Manusia berinteraksi dan berkomunikasi, mencari informasi serta mengendalikan pikiran, sikap dan perbuatan dengan menggunakan bahasa. Kemampuan menggunakan bahasa bukan merupakan kemampuan yang bersifat alamiyah seperti bernapas. Kemampuan ini tidak dibawa sejak lahir dan tidak dapat dikuasai dengan sendirinya melainkan harus dipelajari, salah satunya bahasa Indonesia.

Bahasa indonesia merupakan salah satu mata pelajaran yang diajarkan di dunia pendidikan, khususnya pada jenjang sekolah dasar. Pembelajaran bahasa Indonesia di Sekolah Dasar mempunyai peranan yang sangat penting bagi siswa dalam membentuk kebiasaan, sikap, serta kemampuan dasar yang diperlukan untuk perkembangan selanjutnya. pembelajaran bahasa Indonesia dapat membantu siswa dalam mengembangkan kemampuan bahasa yang 
diperlukan, bukan saja untuk komunikasi melainkan untuk menyerap berbagai nilai serta pengetahuan yang dipelajari. Hal ini selaras dengan tujuan umum dari Pembelajaran bahasa Indonesia di Sekolah Dasar yaitu untuk mengembangkan kemampuan bahasa Indonesia dalam segala fungsinya sebagai sarana komunikasi berfikir, pemersatu, mengembangkan ilmu pengetahuan dan teknologi serta kebudayaan.

"Terampil berbahasa berarti terampil membaca, terampil berbicara, terampil menyimak dan terampil menulis dalam bahasa indonesia yang baik dan benar" (Tarigan 2008). Keempat keterampilan tersebut pada dasarnya merupakan satu kesatuan. Salah satu keterampilan berbahasa yang sangat diperlukan siswa sekolah dasar untuk berkomunikasi adalah keterampilan berbicara. Tidak semua orang dapat dengan mudah memiliki keterampilan berbicara yang baik, namun memerlukan latihan atau pengalaman berbicara.

Pada usia anak sekolah, kemampuan anak dalam mengenal dan menguasai perbendaharaan kata (vocabulary) mengalami perkembangan yang pesat. Sekitar 2.500 kata yang dikuasai oleh anak usia 6 tahun, akan meningkat menjadi 50.000 kata yang bisa dikuasai saat nanti anak berusia 11-12 tahun. Seiring dengan tingkat berpikir anak yang sudah lebih maju, anak akan banyak bertanya soal waktu dan sebab akibat. Maka diharapkan pada periode ini anak bisa memiliki keterampilan mengolah informasi yang di terima, serta berpikir dan menyatakan gagasannya. Namun kenyataannya masih banyak anak usia sekolah belum dapat menyampaikan pendapatnya didepan kelas dengan percaya diri dan belum memiliki keterampilan berbicara yang baik.

Berdasarkan hasil wawancara dengan guru kelas 3 SDN 46 Mataram dan hasil observasi terhadap siswa kelas 3 SDN 46 Mataram, tidak semua siswa memiliki keterampilan berbicara yang baik. Hal tersebut dapat dilihat dari banyaknya siswa yang tidak aktif dalam kegiatan pembelajaran. Ketidak aktifan tampak pada sedikitnya siswa yang berani bertanya dan menjawab pertanyaan guru. Kemudian ada banyak siswa yang kurang lancar dalam berbicara, selain itu kosakata bahasa Indonesia yang digunakan untuk berkomunikasi tidak tepat serta siswa lebih sering menggunakan bahasa daerah yang bermakna kasar dan tidak sopan jika digunakan pada orang yang lebih tua, terlebih lagi jika lawan bicaranya adalah guru. Beberapa hal tersebut membuat penulis tertarik untuk melakukan penelitian ini, ketidakcakapan dalam berbicara akan berdampak pada kehidupan siswa, karena kehidupan sehari-hari membutuhkan komunikasi dan alat berkomunikasi paling efektif adalah dengan berbicara.

Permasalahan tersebut dikarenakan perkembangan pembelajaran bahasa Indonesia di sekolah dasar dalam peningkatan keterampilan berbicara belum begitu maksimal diberikan kepada siswa. Metode yang dipilih dalam melaksanakan proses pembelajaran belum mampu mendorong siswa untuk mengembangkan kemampuan berbicara. Pembelajaran keterampilan berbicara belum bervariasi, guru masih banyak mengajarakan konsep pembelajaran berbicara hanya menggunakan latihan-latihan yang terdapat di buku-buku teks. Suyanto (2005) menyatakan bahwa untuk melatih anak berkomunikasi secara lisan yaitu dengan melakukan kegiatan yang memungkinkan anak berinteraksi dengan teman dan orang lain. Dari pernyataan tersebut dapat disimpukan bahwa perlu ada metode pembelajaran yang dapat memungkinkan interkasi pada siswa. Sehingga diharapkan dapat berpengaruh positif terhadap keterampilan berbicara siswa sekolah dasar.

Suyatno (2004) memaparkan 12 metode pembelajaran yang dapat menjadi pilihan 
dan dikembangkan untuk melaksanakan pembelajaran keterampilan berbicara diantaranya yaitu : (a) wawancara, (b) cerita berpasangan, (c) pidato tanpa teks, (d) pidato dengan teks, (d) pidato dengan teks, (e) mengomentari film atau cerpen, (f) debat, (g) menjadi pembawa acara, (h) pemimpin rapat, (i) menerangkan obat atau benda, (j) bermain peran, (k) info berantai, (l) cerita berangkai. Salah satu dari 12 metode yang sesuai untuk dipilih dalam pembelajaran keterampilan berbicara adalah metode bermain peran.

Bermain Peran merupakan salah satu metode pembelajaraan yang dapat diterapkan guru untuk mengembangkan keterampilan berbicara siswa. Hal tersebut tidak banyak dilakukan oleh guru, sehingga penelitian ini diharapkan dapat memberikan inspirasi dan manfaat dalam pengembangan keterampilan berbicara di SDN 46 Mataram. Sanjaya (2007) mengemukakan bahwa bermain peran adalah metode pembelajaran sebagai bagian dari simulasi yang diarahkan untuk mengkreasikan peristiwa sejarah, mengkreasikan peristiwa-peristiwa aktual, atau kejadian-kejadian yang mungkin muncul pada masa mendatang. Hal tersebut dikuatkan oleh pendapat Suryani (2008) yang menjelaskan bahwa bermain peran adalah memerankan karakter/tingkah laku dalam pengulangan kejadian yang diulang kembali, kejadian masa depan, kejadian masa kini yang penting atau situasi imajinatif. Melalui bermain peran siswa akan berbicara layaknya orang yang sedang ditirunya. Siswa akan menirukan ekspresi, mimik muka, tingkah dan perilaku seseorang yang diperankannya. Dengan demikian melalui metode bermain peran, kecerdasan linguistik atau perkembangan bahasa anak khususnya keterampilan berbicara dapat meningkat karena dalam pembelajaran ini anak akan lebih banyak berbicara.

Untuk mencari tingkat hubungan dari penerapan metode bermain peran dan keterampilan berbicara siswa, maka penulis melakukan penelitian yang berjudul "Korelasi Antara Metode Bermain Peran dengan Keterampilan Berbicara Siswa Sekolah Dasar".

\section{B.METODE}

Penelitian ini merupakan penelitian kuantitatif dengan menggunakan pendekatan deskriptif korelasional. Sandjaja dan Heriyanto (2006) mengungkapkan bahwa penelitian korelasional ditujukan untuk mengetahui hubungan suatu variabel dengan variabel-variabel yang lain. Hubungan antar variabel dinyatakan dengan besarnya koefisien korelasi. Variabel yang diteliti yaitu metode bermain peran dan keterampilan berbicara. Penelitian dilakukan pada semester ganjil tahu pelajaran 2019/2020. Rincian pelaksanaan kegiatan, hari pertama mempersiapkan perangkat pembelajaran dan perlengkapan bermain, hari kedua treatment 1 kemudian posttest 1 berupa instrument observasi keterampilan berbicara dan angket metode bermain peran, hari ketiga treatment 2 kemudian posttest 2 , dan hari terakhir wawancara dengan guru.

Populasi dalam penelitian ini adalah siswa kelas III SDN 46 Mataram. Pemilihan sekolah tersebut dilatarbelakangi oleh hasil observasi awal yang menunjukkan bahwa tidak semua siswa memiliki keterampilan berbicara yang baik. Pemilihan sampel yang digunakan adalah teknik Nonprobablity Sampling tipe sampling jenuh artinya seluruh siswa kelas III SDN 46 Mataram yang berjumlah 30 siswa merupakan sampel pada penelitian ini. Metode pengumpulan data yang digunakan dalam penelitian ini ialah observasi, angket dan wawancara dengan instumrn lembar observasi keterampilan berbicara siswa, angket metode bermain bermain peran serta daftar pertanyaan wawancara terhadap guru.

Adapun metode analisis data yang digunakan adalah uji normalitas data dan uji hipotesis. Uji normalitas menggunakan uji kolmogorov smirnov, uji hipotesis menggunakan rumusan korelasi Product 
Moment. Masing-masing uji tersebut dibantu dengan program analisis statistik yakni SPSS.

\section{C.HASIL DAN PEMBAHASAN \\ Hasil}

\section{Hasil Angket Metode Bermain Peran}

Data metode bermain peran yang dikumpulkan dalam penelitian ini menggunakan metode angket dengan skala Likert. Skala Likert yaitu skala yang dapat dipergunakan untuk mengukur sikap, pendapat, dan persepsi seseorang atau sekelompok orang mengenai suatu gejala atau fenomena pendidikan. Skala pengukuran ini menghasilkan pertanyaan dalam bentuk checklist, dengan jawaban yang dibuat skor tertinggi (selalu) tiga dan terendah (tidak pernah) satu. Pelaksanaan pengisian angket yang dilakukan oleh subjek penelitian dimulai pada tanggal 23 Juli sampai dengan 25 Juli 2019 yang telah dilakukan oleh guru kelas III SDN 46 Mataram yang bernama ibu Indriyani Adnan, S.Pd. Dari hasil analisis data maka diperoleh hasil pengisian angket tentang keterampilan mengajar guru seperti yang tergambar dalam tabel 4.1 berikut ini:

Tabel 1. Hasil Angket Keterampilan Mengajar Guru

\begin{tabular}{ccc}
\hline Skor Angket & Frekuensi & Kategori \\
\hline 3 & 18 & Selalu \\
\hline 2 & 11 & Kadang-kadang \\
\hline 1 & 1 & Tidak pernah \\
\hline$\sum \mathbf{X}=\mathbf{7 7}$ & $\mathbf{N = 3 0}$ & \\
Rata-rata & $\mathbf{8 5 , 5 5}$ & BAIK \\
\hline
\end{tabular}

Dari tabel 1 dapat dilihat bahwa dari 30 item pernyataan, jumlah item yang dicentang pada kategori selalu dengan skor 3 adalah 18 item, kemudian jumlah item pernyataan pada kategori kadang-kadang dengan jumlah skor 2 adalah 11 item, dan jumlah item yang dicentang pada kategori tidak pernah dengan jumlah skor 1 adalah 1 item pernyataan. Sehingga didapatkan total skor yaitu 77 yang kemudian dibagi skor maksimal yaitu 90 dan dikalikan $100 \%$ dan dari perhitungan data tersebut dapat diketahui nilai rata-ratanya yaitu 85,55.

\section{Hasil Observasi Keterampilan Berbicara Siswa}

Data keterampilan berbicara siswa dalam penelitian ini diperoleh dari hasil obervasi peneliti ketika sedang diterapkannya metode bermain peran didalam kelas oleh guru. Observasi ini bertujuan untuk mengamati bagaimana keterampilan berbicara siswa didalam kelas ketika sedang diterapkannya metode bermain peran. Observasi dilakukan sebanyak 2 kali disesuaikan dengan banyaknya penerapan metode bermain peran yang dilaksanakan. Dari hasil observasi tersebut maka didapatkan hasil analisis data statistik deskriptif frekuensinya dengan berbantuan program Microsoft office excel sebagai berikut:

Tabel 2. Hasil Observasi Keterampilan berbicara siswa

\begin{tabular}{ccc}
\hline Skor & Frekuensi & Kategori \\
\hline $26-32$ & 14 & Sangat baik \\
\hline $19-25$ & 15 & Baik \\
\hline $13-18$ & 1 & Cukup baik \\
\hline $7-12$ & 0 & Kurang baik \\
\hline $0-6$ & 0 & Tidak baik \\
\hline$\sum \mathbf{X}=\mathbf{7 5 0}$ & $\mathbf{N = 3 0}$ & \multirow{2}{*}{ BAIK } \\
\hline Rata-rata & $\mathbf{7 8 , 1 2}$ & \\
\hline
\end{tabular}

Dari tabel 2 dapat dilihat bahwa dari 30 siswa, jumlah siswa yang terdapat pada sangat baik dalam keterampilan berbicaranya dengan skor dari 26-32 adalah 14 orang. Jumlah siswa yang terdapat pada baik dalam keterampilan berbicaranya dengan jumlah skor 19-25 adalah 15 orang, 
sedangkan jumlah siswa yang terdapat pada dikategori cukup baik dalam keterampilan berbicaranya dengan jumlah skor 13-18 adalah 1 orang. Sehingga didapatkan total skor yaitu 750 yang kemudian dibagi skor maksimal yaitu 960 dan dikalikan $100 \%$ dan dapat diketahui bahwa secara keseluruhan nilai rata-rata yang diperoleh sebesar 78,12. Artinya rata-rata keterampilan berbicara siswa kelas III SDN 46 Mataram masuk dalam kategori baik.

\section{Korelasi Penerapan Metode Bermain Peran Terhadap Keterampilan Berbicara}

a) Uji Normalitas

Uji normalitas data dilakukan untuk mengetahui apakah data bermain peran dan data keterampilan berbicara siswa yang didapatkan memiliki distribusi normal atau tidak. Data yang sudah normal merupakan syarat dalam melakukan analisis statistik parametrik. Uji normalitas dalam penelitian ini adalah menggunakan Uji KolmogorovSmirnov dengan bantuan SPSS 16.0.

Berdasarkan hasil analisis data menggunakan Uji Kolmogorov-Smirnov didapatkan nilai signifikansi sebesar 0,667, berdasarkan kriteria pengujiannya adalah data distribusi normal jika pada taraf signifikasi > 0,05 dan untuk distribusi tidak normal jika taraf signifikasi < 0,05. Jadi dapat dikatakan bahwa data analisis diatas berdistribusi normal karena nilai signifikansi sebesar 0,667 lebih besar dari 0,05.

b) Uji Hipotesis

Setelah melakukan uji normalitas data, diperoleh hasil analisis data terdistribusi normal sehingga uji hipotesis dapat dilakukan. Hipotesis merupakan jawaban sementara atas masalah yang dirumuskan. Hipotesis pada penelitian ini yang disebet $\mathrm{H}_{\mathrm{a}}$ yaitu ada korelasi antara penerapan metode bermain peran dengan keterampilan berbicara siswa Sekolah Dasar. Sedangkan H0 untuk penelitian ini yaitu tidak ada korelasi anataran penerapan metode bermain peran dengan keterampilan berbicara siswa Sekolah Dasar. Hipotesis ini harus diuji kebenarannya secara empiris. Uji hipotesis dalam penelitian ini menggunakan rumus korelasi Product Moment dibantu dengan program SPSS 16.0 for windows. Berikut hasil uji korelasi sederhana antara variabel metode bermain peran dengan hasil keterampilan berbicara siswa kelas III SDN 46 Mataram Tahun Pelajaran 2019/2020. Hasil analisis disajikan dalam tabel 3 berikut:

Tabel 3 Hasil Uji Hipotesis

\begin{tabular}{llrr}
\multicolumn{3}{c}{ Correlations } \\
\hline & $\begin{array}{c}\text { Metode } \\
\text { Bermain } \\
\text { Peran }\end{array}$ & $\begin{array}{c}\text { Keterampilan } \\
\text { Berbicara }\end{array}$ \\
\hline Metod & $\begin{array}{l}\text { Pearson } \\
\text { e }\end{array}$ & 1 & .613 \\
$\begin{array}{l}\text { Cerrelation } \\
\text { in }\end{array}$ & Sig. (2-tailed) & & .002 \\
$\begin{array}{l}\text { Peran } \\
\text { Ketera }\end{array}$ & Pearson & 30 & 30 \\
mpilan & Correlation & -.313 & 1 \\
$\begin{array}{l}\text { Berbic } \\
\text { ara }\end{array}$ & Sig. (2-tailed) & .092 & \\
& $\mathrm{~N}$ & 30 & 30 \\
\hline
\end{tabular}

Berdasarkan tabel tersebut, diketahui nilai signifikansi sebesar 0,002 sehingga dilihat dari dasar pengambilan keputusan pada penelitian ini yaitu jika nilai signifikan $<0,05$ maka $\mathrm{H}_{\mathrm{a}}$ diterima dan $\mathrm{H}_{\mathrm{o}}$ ditolak, artinya ada korelasi yang signifikan antara metode bermain peran dan keterampilan berbicara siswa. Sebaliknya, apabila nilai signifikan > 0,05 maka $\mathrm{H}_{\mathrm{a}}$ ditolak dan $\mathrm{H}_{\mathrm{o}}$ diterima, artinya tidak ada korelasi yang signifikan antara metode bermain peran dan keterampilan berbicara siswa.

Hal ini menunjukkan bahwa terdapat korelasi antara penerapan metode bermain peran terhadap keterampilan berbicara siswa kelas III SDN 46 Mataram Tahun Pelajaran 2019/2020. Sementara itu, dapat disimpulkan bahwa tingkat korelasi antara 
penerapan metode bermain peran terhadap keterampilan berbicara siswa kelas III SDN 46 Mataram Tahun Pelajaran 2019/2020 berada pada rentang 0,613 yang berarti berkategori kuat.

\section{Pembahasan}

Penelitian ini membahas tentang korelasi penerapan metode bermain peran dengan keterampilan berbicara siswa kelas III SDN 46 Mataram Tahun Pelajaran 2019/2020. Tujuan dari penelitian ini untuk mengidentifikasi tingkat keterampilan berbicara siswa jika guru menerapkan metode bermain peran di dalam kelas, serta untuk mengidentifikasi ada atau tidaknya korelasi antara penerapan metode bermain peran dengan keterampilan berbicara siswa kelas III SDN 46 Mataram Tahun Pelajaran 2019/2020.

Berdasarkan hasil penelitian yang telah dipaparkan sebelumnya, dapat diketahui bahwa skor untuk pelaksanaan metode bermain peran yang diterapkan oleh guru memiliki rata-rata 85,55 , hal ini menunjukan bahwa guru dapat menggunakan metode bermain peran sesuai dengan tahapannya dan sudah berkategori baik. Artinya metode bermain peran telah dilaksanakan dengan baik dan guru sudah dapat melaksanakannya dengan benar sesuai dengan langkah yang ditentukan. Langkah-langkah metode bermain peran terdiri atas beberapa langkah yaitu: a) pemanasan, b) memilih pemain, c) menata panggung/lokasi, d) guru menunjuk beberapa siswa sebagai pengamat, e) permainan peran dimulai, f) diskusi dan evaluasi (Hamzah, 2011).

Adapun komponen tahapan metode bermain peran yang digunakan merupakan terdiri dari tahap persiapan, pelaksanaan dan penutup, yang terdiri dari beberapa indikator. Data hasil penerapan metode bermain peran menunjukkan bahwa ada 18 kegiatan yang memang selalu dilakukan guru ketika menerapkan metode bermain peran, dan ada 11 kegiatan yang kadang dilakukan dan kadang tidak dilakukan guru ketika menerapkan metode bermain peran, serta ada 1 kegiatan yang memang tidak pernah dilakukan oleh guru yaitu membiarkan siswa memilihkan perannya dkarenakan guru menggunakan teknik acak dalam penentuan peran. Dari hasil tersebut maka diperoleh skor total 77 untuk semua pernyatan, dan untuk mengetahui rataratanya maka skor total yang diperoleh akan di bagi dengan skor total dari keseluruhan pernyataan dan dikalikan $100 \%$ sehingga didapatkan rata-ratanya 85,55.

Selain angket, penelitian ini menggunakan metode observasi untuk menilai keterampilan berbicara siswa. Sebelum melaksanakan metode bermain peran, keterampilan berbicara siswa kelas III SDN 46 Mataram masih kurang, dimana hal ini terlihat dari sikap dan perilaku siswa yang pasif didalam kelas, sehingga membuat siswa tersebut tidak dapat menerima pembelajaran dengan baik. Kemudian setelah melaksanakan pembelajaran dengan menggunakan metode bermain peran didapatkan hasil ada 14 siswa yang dapat dikategorikan sangat baik (skor 26-32) dalam keterampilan berbicaranya, dan ada 15 siswa yang dapat dikategorikan baik (skor 19-25) dalam keterampilan berbicaranya serta hanya 1 siswa yang dikategorikan cukup baik (skor 13-18) dalam keterampilan berbicaranya. Dari perolehan skor diatas maka didapatkan hasil skor total yang diperoleh 750 yang kemudian akan dibagi dengan skor total keseluruhan item yaitu 960 dan dikalikan dengan 100 sehingga diperoleh hasil rata-rata 78,12.

Berdasarkan hasil tersebut maka dapat disimpulkan bahwa keterampilan berbicara siswa kelas III sudah mencapai kategori baik ketika diterapkannya metode bermain peran oleh guru. Tak berbeda dengan hasil penelitian yang dilakukan oleh Suryani, Arini dan Murda (2016) bahwa keterampilan berbicara siswa mengalami peningkatan dari kategori kurang ke kategori baik setelah 
menerapkan metode pembelajaran bermain peran. Hal ini disebabkan oleh beberapa hal. (1) Siswa melatih dirinya untuk memahami dan mengingat apa yang diperankan (2) siswa menjadi lebih kreatif untuk melakukan sesuatu di dalam kelompoknya (3) bakat yang dimiliki siswa perlahan mulai terlihat dan dapat dibina oleh guru.

Keterlaksanaan proses pembelajaran dengan menggunakan metode bermain peran dan keterampilan berbicara yang telah masuk dalam kategori baik didukung dengan hasil wawancara yang dilakukan kepada guru. Berdasarkan hasil wawancara yang dilakukan terhadap guru kelas III didapatkan hasil bahwa siswa lebih antusias ketika guru menerapkan metode bermain peran. Guru kelas III mengemukakan bahwa dengan menggunakan metode bermain peran siswa menjadi lebih aktif berbicara, siswa mulai terlihat percaya diri berbicara didepan kelas dan tidak sungkan untuk bertanya kepada guru. Selain itu, siswa menjadi lebih ikut berperan dalam pembelajaran karena terlibat langsung dan mengetahui maksud dari peran yang dilakoni, dampak positif dari kemajuan keterampilan berbicara siswa tersebut yaitu guru dapat mengetahui hal-hal yang tidak dimengerti siswa sehingga siswa dapat menerima pembelajaran dengan baik dan dapat berkomunikasi dengan baik dengan teman-temannya. Metode bermain peran juga membuat siswa yang pasif dan pendiam menjadi lebih aktif dan banyak berbicara, oleh karena itu dapat disimpulkan bahwa metode bermain peran dapat dikategorikan sebagai metode yang dapat digunakan oleh guru sebagai cara meningkatkan keterampilan berbicara siswa. Hasil tersebut sejalan dengan penelitian yang dilakukan Siska (2011) yang hasilnya penerapan metode bermain peran memberikan kontribusi yang sangat besar pada keterampilan berbicara anak di TK AlKautsar kelas B, hal tersebut tampak pada anak-anak yang tadinya ragu ketika bermain peran dan berinteraksi serta berbicara, sudah tidak ragu lagi untuk memainkan perannya, anak sudah dapat melakukan kontak mata serta merespon pembicaraan, ikut serta dalam kegiatan kelompok dan anak sudah dapat berbicara dengan leluasa.

Hasil dari penelitian dikonfirmasi dengan uji hipotesis untuk menentukan korelasi anatara metode bermain peran dengan keterampilan berbicara siswa kelas III SDN 46 Mataram. Sebelum melakukan uji hipotesis, perlu dilakukan uji prasyarat terlebih dahulu yaitu uji normalitas data. Berdasarkan uji normalitas dengan bantuan aplikasi SPSS 16.0 for windows didapat nilai keterampilan berbicara dan metode bermain peran Sig.(2-tailed) $=0,667$ dengan nilai $\alpha=$ 0,05 , maka data dapat dinyatakan berdistribusi normal, karena Sig $>\alpha(0,05)$. Setelah data keterampilan berbicara dan metode bermain peraan dinyatakan berdistribusi normal maka langkah selanjutnya, yaitu dengan menguji hipotesis menggunakan Pearson Product Moment. Hasil perhitungan pengujian hipotesis didapatkan nilai signifikansi sebesar 0,002 sehingga dilihat dari dasar pengambilan keputusan pada penelitian ini yaitu jika nilai signifikan $<0,05$ maka $\mathrm{H}_{\mathrm{a}}$ diterima dan $\mathrm{H}_{\mathrm{o}}$ ditolak, artinya ada korelasi yang signifikan antara metode bermain peran dan keterampilan berbicara siswa. Sebaliknya, apabila nilai signifikan $>0,05$ maka $\mathrm{H}_{\mathrm{a}}$ ditolak dan $\mathrm{H}_{\mathrm{o}}$ diterima, artinya tidak ada korelasi yang signifikan antara metode bermain peran dan keterampilan berbicara siswa, maka dari itu dapat dinyatakan bahwa hipotesis $\left(H_{a}\right)$ diterima. Berdasarkan hasil uji hipotesis yang telah dilakukan tingkat korelasi yang didapatkan yaitu berada pada rentang 0,613, artinya dapat disimpulkan bahwa tingkat korelasi antara penerapan metode bermain peran dengan keterampilan berbicara siswa kelas III SDN 46 Mataram Tahun Pelajaran 2019/2020 berkategori kuat.

Korelasi yang ada antara penerapan metode bermain peran dengan keterampilan 
berbicara pada penelitian ini sejelan dengan penelitian sebelumnya yang dilakukan oleh Ernani dan Syarifudin (2016) yang berjudul "Pengaruh Metode Role Playing Terhadap Keterampilan Berbicara Siswa Pada Mata Pelajaran Bahasa Indonesia Kelas $\mathrm{V}$ di Madrasah Ibtidaiyah Wathoniyah Palembang". Hasil penelitian menunjukkan bahwa metode role playing atau dalam bahasa Indonesia disebut bermain pernah berpengaruh positif terhadap keterampilan berbicara siswa dengan hasil perhitungan t0 $>$ tt dengan hasil yaitu $2,05<53,9>2,77$. Jadi, karena t0 lebih besar daripada tt maka hipotesis nihil yang diajukan ditolak, ini berarti bahwa adanya pengaruh penerapan metode role playing terhadap keterampilan berbicara siswa pada mata pelajaran Bahasa Indonesia di Madrasah Ibtidaiyah Wathoniyah Palembang.

Meskipun dinilai berhasil, proses pembelajaran dengan menggunakan metode bermain peran juga memiliki kendala dalam pelaksanaannya diantaranya yaitu pembiasaan guru menggunakan metode baru, sarana dan prasarana sekolah yang belum mendukung, alokasi waktu pelaksanaan yang cukup lama dan melekatnya bahasa daerah yang menjadi bahasa pergaulan siswa. Hal tersebut sejalan dengan hasil penelitian Siska (2011), salah satu kendala penerapan bermain peran yaitu budaya dan bahasa pergaulan siswa yang sangat melekat. Meskipun berada di kota, siswa masih banyak yang menggunakan bahasa daerah dalam pergaulan bahkan terbawa hingga pada proses pembelajaran. Sebagian besar siswa lebih nyaman menggunakan bahasa sasak sebagai bahasa komunikasi, hal tersebut sebagai aplikasi dari kebudayaan masyarakat Lombok yang diwariskan dari orang tua siswa. Seperti halnya pernyataan dari Rubdhi (2017) bahwa lingkungan keluarga menjadi salah satu fokus kajian antropologi pendidikan, terutama mengenai sistem pewarisan kebudayaan.
Pewarisan kebudayaan yang dilakukan orang tua bertujuan untuk melestarikan kebudayaan, akan tetapi akan lebih bijak jika sebagai bangsa Indonesia dapat menggunakan bahasa sesuai dengan tempat dan waktunya. Menurut Mugni (2016) pemertahanan bahasa terjadi jika suatu bahasa dipakai berdampingan dengan bahasa yang lain. Bahasa yang dipertahankan tidak terpengaruh dengan bahasa yang lain. Artinya penguasaan bahasa lain selain bahasa daerah penting, ketika sedang bermain dapat menggunakan bahasa daerah akan tetapi ketika sedang proses pembelajaran dapat menggunakan bahasa Indonesia. Bahasa Indonesia merupakan bahasa wajib yang harus dikuasai oleh seluruh masyarakat Indonesia karena merupakan bahasa nasional yang dapat menyatukan perbedaan yang melekat pada bangsa Indonesia. Hal tersebut sejalan dengan pendapat Muslim (2016) bahwa kekuatan bahasa Indonesia dalam menghimpun perbedan-perbedaan setiap suku dan budaya yang berkembang di tengah-tengah masyarakat yang multikultural, multietnis, dan multilingual telah menjadi salah satu energi dan motivasi yang perlu diapresiasi oleh seluruh masyarakat Indonesia.

Selain berhubungan dan berpengaruh terhadap keterampilan berbicara dalam bahasa Indonesia, metode bermain peran juga berpengaruh positif untuk perkembangan keterampilan berbicara pada bahasa asing. Hal tersebut dibuktikan dengan hasil penelitian yang dilakukan oleh Hidayah (2017) yang menyatakan bahwa metode role playing (bermain peran) dapat melatih penguasaan bahasa yang baik dan benar serta penguatan kompetensi dalam berbahasa yang kreatif dan inovatif dan menjadikan peserta didik belajar bahasa Arab lebih dewasa dan matang di lingkungannya. Selain bahasa Arab, terdapat pengaruh positif pembelajaran dengan teknik bermain peran terhadap keterampilan 
berbicara bahasa Inggris. Hasilnya menyatakan kesimpulan bahwa semakin banyak guru menggunakan pembelajaran dengan metode bermain peran dalam pembelajaran bahasa Inggris, maka akan menghasilkan keterampilan berbicara bahasa Inggris yang baik pula (Prasetyo, Anggoro dan Santosa, 2018).

\section{SIMPULAN}

Berdasarkan analisis data pada hasil dan pembahasan penelitian tentang "Korelasi Antara Metode Bermain Peran dengan Keterampilan Berbicara Siswa Sekolah Dasar", didapatkan hasil sebagai berikut :

1. Pelaksanaan metode bermain peran yang diterapkan guru kelas III SDN 46 Mataram tahun pelajaran 2019/2020 tergolong baik dengan nilai rata-ratanya yaitu 85,55.

2. Hasil observasi mengenai keterampilan berbicara siswa kelas III SDN 46 Mataram tahun pelajaran 2019/2020 tergolong baik dengan nilai rata-rata yang diperoleh sebesar 78,12.

3. Hasil uji hipotesis dalam penelitian ini yaitu $H_{a}$ diterima dan $H_{0}$ ditolak, yang berarti terdapat korelasi yang signifikan antara penerapan metode bermain peran dengan keterampilan berbicara siswa kelas III SDN 46 Mataram tahun pelajaran 2019/2020, yakni nilai signifikansi sebesar 0,002 yang berarti < 0,05 maka $\mathrm{H}_{\mathrm{a}}$ diterima dan $\mathrm{H}_{\mathrm{o}}$ ditolak dan juga memiliki tingkat korelasi 0,613 berada pada kategori kuat.

\section{DAFTAR PUSTAKA}

Ernani dan Ahmad Syarifuddin. (2016). Pengaruh Metode Role Playing Terhadap Keterampilan Berbicara Siswa Pada Mata Pelajaran Bahasa Indonesia Kelas V di Madrasah Ibtidaiyah Wathoniyah Palembang. Jurnal Ilmiah PGMI, Volume 2, Nomor 1, Januari 2016. Hlm 29-42
Hamzah, B. Uno. (2011). Model Pembelajaran: Menciptakan Proses Belajar Mengajar yang Kreatif dan Efektif. Jakarta: Bumi Aksara

Hidayah, Nurul. (2017). Pengembangan Keterampilan Berbicara dengan Metode Role Playing pada Mata Pelajaran Bahasa Arab. Jurnal Kependidikan IAIN Purwokerto, Volume 5, Nomor 1, 1 Mei 2017, hlm $1-9$

Mugni. (2016). Pemertahanan Bahasa Sasak pada Keluarga Bangsawan Lombok (Studi Etnografi di Kabupaten Lombok Timur). Jurnal Linguistik, Sastra, Dan Pendidikan (JURNALISTRENDI), Volume 1, Nomor 1, Tahun 2016

Muslim, Bukhori. (2016). Ancaman Bahasa Indonesia dalam Dunia Pariwisata di NTB. Jurnal Linguistik, Sastra, Dan Pendidikan (JURNALISTRENDI), Volume 1, Nomor 1, Tahun 2016, hlm. $1-8$

Prasetyo, Agung; Doni Anggoro dan Ari Santoso. (2018). Pengaruh Teknik Bermain Peran Terhadap Keterampilan Berbicara. Jurnal Deiksis, Volume 10, Nomor 2, MeiAgustus 2018, hlm 85-91

Rubdhi, Muhamad. (2017). Leksikon Bahasa Sasak Dalam Ranah Keluarga di Masyarakat Desa Batulayar Kecamatan Batulayar Kabupaten Lombok Barat. Jurnal Linguistik, Sastra, Dan Pendidikan (JURNALISTRENDI), Volume 2, Nomor 2, Tahun 2017, hlm 120-130

Sandjaja, B dan Albertus Heriyanto. (2006). Panduan Penelitian. Jakarta: Prestasi Pustakaraya 
Sanjaya, Wina. (2007). Strategi Pembelajaran Berorientasi Standar Proses Pendidikan. Jakarta : Kencana Prenada Media Group

Siska, Yulia. (2011). Penerapan Metode Bermain Peran (Role Playing) dalam Meningkatkan Keterampilan Sosial dan Keterampilan Berbicara Anak Usia Dini. Jurnal edisi khusus UPI, Nomor 2, Agustus 2011, hlm. 31-37

Suryani, $\quad$ Lilis.(2008). Metode Pengembangan Perilaku dan Kemampuan Dasar Anak Usia Dini. Jakarta: Universitas Terbuka

Suryani, Kd. Ayu Budi; Ni Wyn Arini; dan I Nyn. Murda. (2016). Penerapan Metode Bermain Peran untuk Meningkatkan Keterampilan Berbicara Siswa Kelas III SD No 4 Penarukan. e-Journal PGSD Universitas Pendidikan Ganesha Jurusan PGSD, Vol 4, No 1, Tahun 2016, hlm. 1-10

Suyanto, Slamet. (2005). Konsep Dasar Anak Usia Dini : Jakarta : Departemen Pendidikan Nasional

Suyatno. (2004). Teknik Pembelajaran Bahasa dan Sastra. Surabaya: SIC

Tarigan, Henry Guntur. (2008). Berbicara Sebagai Suatu Keterampilan Berbahasa. Bandung: Angkasa 